DE DE GRUYTER OPEN
Journal of Intercultural Management

Vol. 6, No. 4, December 2014, pp. 245-262

DOI 10.2478/joim-2014-0049

Katarzyna Kolasińska-Morawska*

University of Social Sciences

\title{
Success and entrepreneurship in the eyes of Polish emigrants in the British Isles
}

\begin{abstract}
This article is dedicated to the problems of success as interpreted by Polish emigrants living in the British Isles. The study begins with a presentation of selected views of success. There are then considerations of matters connected with the verification of the essence of success in terms of motivation and the values espoused in a given culture. Next is a discussion of the role and importance of the predestination of entrepreneurship as an indicator of success in the business field. A vital ingredient of those considerations was an analysis of the motives behind emigration as a phenomenon which liberates entrepreneurial actions. It is on this basis that the results are presented of the author's own research into success a understood in terms of entrepreneurship as understood by Polish emigrants living in the British Isles.
\end{abstract}

Key words: success, entrepreneurship, motivation, emigration

\section{Introduction}

The turbulent socio-economic space into which contemporary societies are plunged affects the attitudes, opinions and decision-making processes of their citizens with regard to choosing their paths for both personal and professional development. On the other hand, the knowledge, skills and qualifications combined with citizens' personal predispositions may be only be fully exploited wherever there exist legal and economic regulations which are conducive to this and allow them to realise their dreams and ambitions. This process is exemplified by, for example, the mental self-identification of individuals in categories of success, whether in the personal or professional field.

The aim of this paper is to present the attitudes and opinions about success, particularly success in business, seen in terms of entrepreneurship of emigrants.

\footnotetext{
*kkolasinska@spoleczna.pl
} 
According to the author the issue of success is important in terms of cognitive and executive as well. Almost more than twenty years research institutes and organizations in the area of entrepreneurship deepen and native entrepreneurs operating in Poland. Against this background area of research on entrepreneurship Polish emigration is rather weakly been examined. Although efforts in this direction taken by institutes such as the Centre for Migration Research and CEED Institute and many researchers including B. Glinka [Glinka 2013], M. Lesińska, M. Okólski [Lesińska, Okólski 2013] and P. Kaczmarczyk [Kaczmarczyk 2011, 2014] the area relating to emigration as exemplification of significance in the unit external stimulation of entrepreneurial behaviors that lead to success on the basis of the business are weak. Knowledge on this topic is still very small. Understanding of success in Polish literature through the prism of entrepreneurship Poles living abroad is treated in the marginal [Grabowska - Lusińska, Okólski 2009], which speaks for the fact that there is a gap in this area, which should be filled. Analyzing business success as a consequence of entrepreneurial activities from the perspective of management sciences is important both in terms of cognitive, as the executive. Recognition of factors motivating immigrants to entrepreneurial activity will bring about improvements in the area of social policy in particular with regard to the development of tools to support the process of stopping the exodus of well-educated young people or causing the return of those who have already left.

Realising the aim adopted in this way required the author to obtain answers to the following constituent questions - can success be defined unambiguously? what determines success? who is a successful person? what has motivation to do with success? what importance does a system of values have on the road to success? what does being entrepreneurial mean? why do Poles decide to emigrate?

The material gathered serves as a background for a presentation of the research material on the quantification of success from the perspective entrepreneurship in the opinion of people living as emigrants in Great Britain.

\section{Can success be defined?}

The loudest speaker in the world is success

Napoleon Bonaparte

The word "success" surrounds us on every side. Both in the titles of newspapers $^{1}$, books, internet vortals ${ }^{2}$, articles and films, and in the text of advertising slogans, news reports, competitions ${ }^{3}$, lectures and business conversations, as well as

\footnotetext{
1 Examples of magazines with the word „success” in the title are Magazyn Sukces published in Poland by Gremi Business Communication sp. z o.o., and Success magazine in the US.

2 Examples of such vortals specialising in the topic of success are http://www. sukcespisanyszminka.pl/ and http://kobieta-sukcesu.informativo.pl/

3 A Polish example of this could be Gala Kobiet Sukcesu - http://www.kobietysukcesu.eu/
} 
everyday exchanges of opinions. It could be said that the word success has caught on and become commonplace. On the other hand, every individual occurrence of this word, be it in the media or in ordinary conversations among friends, inspires much emotion. It is worth considering, however, whether everyone who uses the word success really understands it and interprets it correctly, as the use of a given word should result from a person's knowledge, feeling and behaviour confronted with his surroundings.

The word success (Lat. successus) means both the approach and desired result of an undertaking. Its synonyms include accomplishment, achievement, win, victory, triumph, prosperity, gain and progress. It is difficult to give one correct definition, as to paraphrase W. Clement Stone's statement: "The essence of every man's success is the philosophy he espouses"' It can be assumed, then, that there are as many meanings of success as their are statements about it. Everyone sets targets, in other words points in space and time which they aim to reach, when undertaking various activities. It is those targets which predetermine success or failure.

Success is not a single act, but a process combining a series of events. [Qubein 1997, Mackaya 2012] The cause and effect relation in a temporal sense is a result of the essence of success. Conclusions can only be made about success from the perspective of time, when an inductive beginning happens, then a sequence of events and the final effect. Whether or not a given sequence may be labelled a success or failure depends on a range of factors which depend both on the individual and the environment.

Assuming control (as the basic premise in the culture) distinction can be made between the active and passive culture when it comes to people's attitudes to success. In the first foundation of cultural patterns of thinking is a sense of internal control and the latter sense of the external control. The essential differences between the cultures with respect to the value revealed in assigning different valuables objective are associated with different needs. In active culture personal development seems to be much more important while in passive culture - safety. People in these two different cultures define success in different way and have different source of satisfaction. Main value of the active culture is the satisfaction that comes from the use of the disclosed talents and skills. Main value of the passive culture is the satisfaction of social acceptance, which involves the exercise of their social roles properly (a member of the organization, co-worker, family caregiver) which is a source of security [Sikorski 2012]. Poland was for many years an example of a country domination of passive culture could be observed. But as a result of various factors including the ability to move freely between countries and learn about other cultures Poles change their approach in that area as well.

A representation of an individual's opportunities and will to realise his desires and dreams along with a balanced approach to his own existence exemplifies suc- 
cess in every case [Scumaci 2014]. Mention may be made here of success in the categories of expectations or achievements, where the deciding role is played by the value system of a given person [Barszczewski 2013]. This becomes the indicator of success.

A person's existential multidimensionality in turn influences the various ways of categorising success - personal, business, social, etc. This may be seen as success achieved by organisations backed by people, and as successful people.

The frequency of references in the Google search engine show how commonplace this term has become in Poland and around the world. (Fig. 1.).

Figure 1. Statistics of use of the search terms "sukces", "success", "sukces w biznesie" and "success in business" in Google between 2012 - 2014.

\section{sukces}

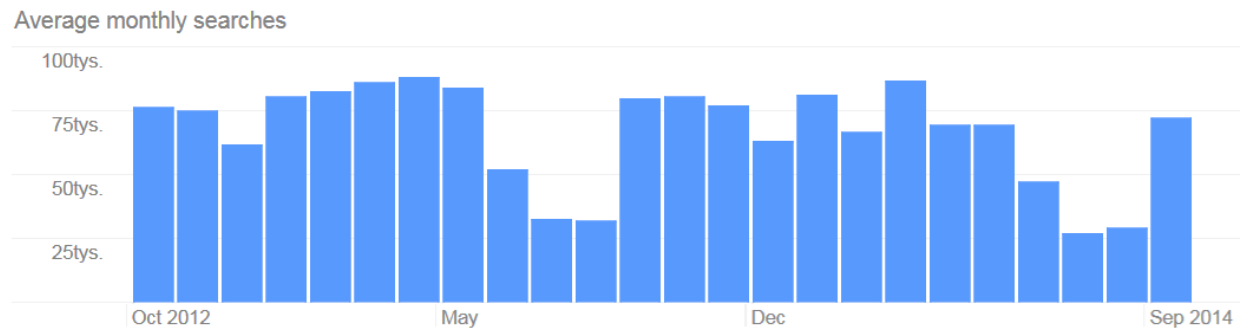

success

Average monthly searches

$8 \mathrm{M}$

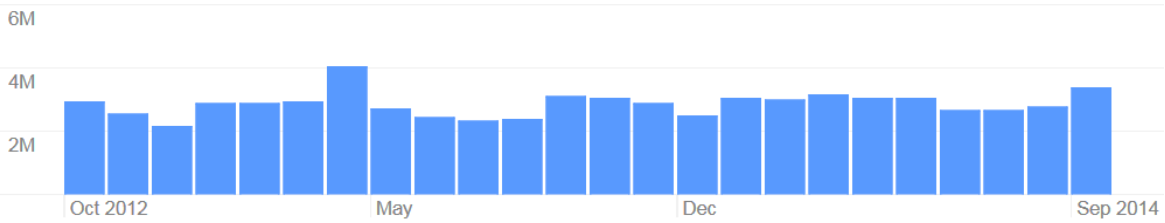

sukces w biznesie

Average monthly searches

4tys.

3tys.

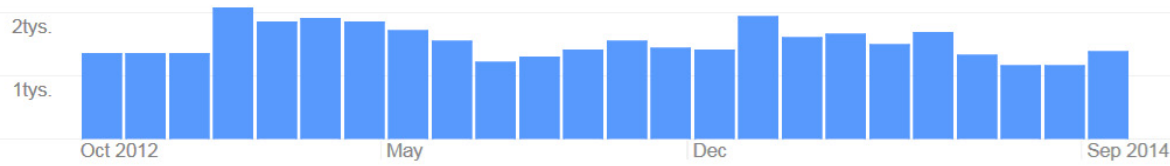




\section{success in business}

Average monthly searches

$4 \mathrm{M}$

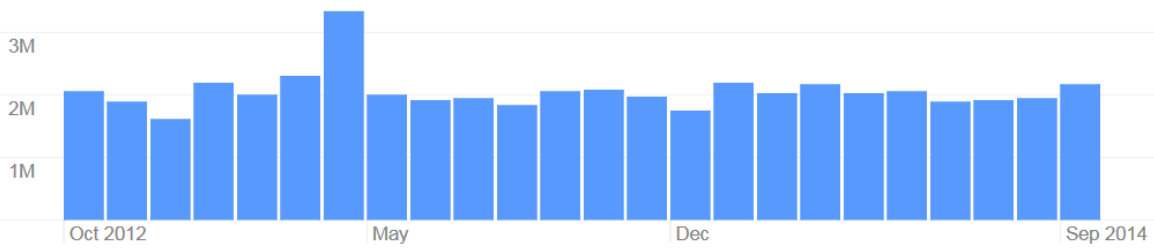

Source: own work based on https://adwords.google.com from 01.11.2014.

The Polish word sukeses has significantly fewer mentions during 2012-2014 than its English equivalent. If we narrow down the definition field to success in business we obtain an illustration of how the number of references in the search engine decreases dramatically, representing a negligible proportion of the search terms entered by internauts. The conclusion is that Polish society does not treat success in business as success. This is unlike the English equivalent, where nearly $50 \%$ uses of the term "success" are compatible with the narrower "success in business". It can thus be assumed that the terms "success" and "success in business" are seen in the world as being analogous, and success in itself is identified more with the business context than the personal one.

\section{What determines success?}

"Iudge your success by the degree that you're enjoying peace, bealth, and love"

H. Jackson Brown Jr

Human beings function within four basic spheres - the body, emotions, intellect and spirit. Although these spheres are connected and interact, they are characterised by different needs and forms of activity. A successful person is a satisfied and happy person. This is not possible without satisfying the needs connected with each of the fields mentioned. [Majewska - Opiełka 2003, p. 36] The principle of maintaining a balance enables people as individuals to achieve success in every field and take satisfaction from this..

The analogy of a company may be used with regard to this view of success, with the fixed assets being the body, the emotions being the relations within the company and between it and its environment, the intellect covering its employees' knowledge and the know-how it possesses, and finally the spirit is represented by the values guiding the company. The aspiration of both a person and an organisation to homeostasis through realisation in these fields becomes the reason for success. It may then be said that achieving revenue and profits is secondary.

It is tempting to state that people managing businesses are responsible for shap- 
ing their own world as well as that connected with the company and its environment, which is a result of the private world overlapping with the professional world, the personal with the social.

Every person plays various roles in life, such as parent, employee and citizen, experiencing the world in each. This experience is often connected with a desire for happiness. Everyone desires happiness, desires success. The sequence of events is worth mentioning here. First of all, a person must feel happy being him or herself, with his or her life. When this is the case, the next step is to guide others in aiming to realise goals - aiming at success. However, Jack Canfield demonstrates that fundamental to creating a road to success is defining its starting point and asking why we are where we are. [Canfield 2005, p. 25]

Failures on this road are seen as merely a basis to learn not to follow a given decision-making path in future. These are an inherent part of the nature of success. There would be no such taste of success without the aftertaste of failure, as in Albert Camus's statement that "It is easy to achieve success, barder to deserve it.

\section{Who is a successful person?}

The label "successful" is ascribed to those who have a vision of their own deeds being ahead of their time. [Altman 1997] Such people have a very good sense of communication and relations. They are insightful observers of the world, they analyse, synthesise and draw conclusions. They demonstrate a creative, almost irrational, approach to problem solving, actively taking on every task. With their charisma and predisposition towards leadership, they are capable of overcoming any adversity. Spiritual strength and the will to fight accompany them continuously in the game called life.

"Our life is what our thoughts make it"

Marcus Aurelius

Successful people are admired. And many would like to be in their place. The force which pushes them to achieve success is, to a large extent, connected to the motivation affecting the state in which highly motivated people are able to overcome the limits of their own potential and achieve significantly more than they had intended. However, it is still true to say that success in business categories does not have to go hand in hand with success and fulfilment in personal life, and often does not. [Nkwocha 2013, p. 16] 


\section{What does motivation have to do with success?}

"You desire not what you see, but what you imagine."

P. Coelho

Motivation is a certain process taking place in human consciousness, resulting in a desire to do something. This desire is known as a motive, purpose or else motivational tension. The motive appears when there exists an awareness of some unsatisfied need, and this is expressed in readiness to take action to satisfy it. However, a motive requires certain conditions to be met. Firstly, there must be a need, in other words a feeling that something is missing. Secondly, that need must be essential - i.e. satisfying it or failing to satisfy it are connected with defined emotional states. Happiness in the first case, sorrow in the second. Thirdly, the person must see some chance of satisfying that need. And finally fourthly, something has to happen as a reminder of that need, or to make it possible or easier to satisfy. In other words a stimulus, also called a motivator, acts. [Sikorski 2007, p. 23] A need connected with a hunger for success refers to defeating the obstacles to performing difficult tasks with maximum use of one's own resources in a given area. As well as the need for success as understood as a negative tension, the literature also includes a qualification of the need for success expressed in categories of achievements. [McClelland 1961, p. 38] This results from the individual externalising the values instilled throughout his or her life. Here the motivation is additionally enhanced by the strength of the challenges taken up to enable individuals to expand the horizons of their own possibilities. A high sense of one's own worth is vital here. Importantly, the person's motivation to meet the challenges set can be shaped by using the appropriate educational system. So we are not born successful people, we become them.

\section{What significance does a system of values have on the road to success?}

"Our whole life is action and passion. By avoiding involvement in the actions and passions of our times,we risk never knowing life."

Herodotus

Someone taking up the challenge of everyday life may approach all the actions either actively or passively, taking into account the control he or she has over the tasks being conducted. The greater the feeling of internal control and self-identification as the perpetrator of the acts, the greater the sense of responsibility and skilful use of one's own abilities. When this matter refers to organisations, it is impossible not to mention the organisational culture which constitutes a system of informal role models and behaviours. Accepting that defined cultural assumptions apply in a given environment, we can indicate the system of value hierarchies 
in forces where its creation is based on individuals' experiences and contacts with other people [Arndt 1998, p. 95 - 100].

The concept of values is understood as meaning the standards which make something more desired, and something else less so. Values are thus the criteria of preference applied by an individual. They function as the criteria for the choices we make when acting. Values fully available to conscious reflection directly become criteria for assessment, preferences and finally the making of a decision. However, even values which are only perceived rather than being subjected to conscious reflection function as if they constituted a basis for a choice of behaviour. [Gładys - Jakóbik 2005, p. 63] Such a system of values becomes a basis for identity and subjectivity, and the basis for the mental balance of the individuals who make up society. The entire world is evaluated to form a reality of values which are the creation of acts of human evaluation. If we add to this the degree of activisation and involvement due to the sense of control felt by the individual,we obtain a division between active and passive culture. In active culture, the foreground is taken by those individuals from the community whose value systems refer to a greater sense of internal control, who feel they are the perpetrators of their own actions and are oriented toward taking up challenges connected with self-development. For passive individuals, a feeling of safety and social acceptance is important. This also means it can be assumed that success will be defined differently by individuals and organisations as such, and by individuals and organisations functioning in different environments which are more or less supportive of them.

The essential component here is the system of standards espoused. Social norms are highly influential in terms of providing strong predestination. In passive culture, social norms refer to social cohesion, humility, modesty and tempering ambitions. There is no room there for individuals. All that matters is the team of people cooperating with one another. In an active culture, though, the accepted type of interpersonal relationships, both at work and in many other social situations, is one of competition. Assertiveness is acceptable, as are open demonstrations of ambitious goals, self-promotion and feistiness. People who behave in this way are appreciated in this culture and held up as role models. Praise for assertiveness and stubborn aiming for individual successes are indicators of a social liberalism as well as of an active culture." [Sikorski 2007, p. 38] One of the vital roles here is played by aspirations.

Aspirations as desires or aims by an individual to achieve are connected with intentions in the field of life plans and the wishes to which that individual subordinates his system of motivations, desires, values and goals. The level of aspiration is different for different people depending on the socio-economic/political environment in which they function. Depending on the role models and value systems instilled by a given society, which are to a certain extent a reflection of the system 
of socialisation. Success-oriented societies will take real actions towards realising their own ambitions. And even though not everyone fully verbalises their desire for success, they do adopt defined targets to achieve, which is a de facto expression of their aspirations through a desire for success. For one person success will be learning a new language, for another promotion at work, for yet another founding and running their own business. Declarations are not enough. Actions must be taken, the strength of the entrepreneurial spirit must be shown.

\section{What does being entrepreneurial mean?}

"The best way to predict the future is to create it." - Peter Drucker

In this context, being entrepreneurial involves a set of traits and behaviour which are oriented towards creating the future, towards achieving success. These characterise all those people who declare their readiness and have the capability to creatively undertake challenges and solve problems, and in doing so make use of the chances which arise in their economic environment.

An entrepreneurial person is one characterised by diligence, creativity, inventiveness, courage and determination. It is a person who is not afraid of risk, who can set out goals and aim to meet them. Such people use their interpersonal skills to manage teams of people. Entrepreneurial people are not afraid of difficult situations. They have an optimistic view of the world and people, and are prepared to undertake life-long learning. They are people with their sights set on the future and on success.

By analysing considerations in this way especially through the perspective of the economic nature of humans (bomo oeconomicus) [Morawski 2001, p. 25] it can be said that humans are entrepreneurial by nature. People understood in this way are guided in their actions by their own interest, in a very narrow sense. To achieve their aims they must calculate, applying purely utilitarian criteria such as profit achieved or predicted loss. However, using these requires them to already have the abilities to define accurately and then make use of the capital - resources - they possess. [Gładys - Jakóbik 2005, p. 30]

For intentions to be realised and an entrepreneurial spirit to form in reality, it is necessary for the economic, social and political system of a given country to be supportive of entrepreneurship. Otherwise, if it is only possible then people emigrate. They emigrate from a given country in search of a better future. 


\section{Why emigration?}

"Home is not where you live, but where they understand you."

Ch. Morgenstern

After the liberalisation of the border policy and Poland's accession to the structures of the European Union, there began a process of emigration of Poles to countries with a higher socio-economic status. The initial phase of emigration has not slowed down, quite the reverse. A decade has now passed since European integration and emigration has not lessened. It is estimated that at the end of 2013, the population of Poland stood at 38,496,000, with $2.2 \mathrm{~m}$ Polish citizens living abroad. The number of emigrants increased by around $0.1 \mathrm{~m}$ people compared to 2012. In reality, this number may be even higher, varying around 2.6 to $2.7 \mathrm{~m}$ when the grey economy is taken into consideration. Poles most often move to Britain $(650,000)$ and Germany $(550,000)$. Other countries chosen as new homelands are Ireland (115,000), Holland (103,000), Norway (71,000) and France (63,000). [GUS 2013] A clear majority of those who decided to emigrate did so for mainly economic reasons. Poles have left and are leaving in search of better work. Not just work as such, which they could not do in Poland, but better paid and more attractive jobs in line with their interests and aspirations.

Table 1. Willingness to work abroad (as a \%)*

\begin{tabular}{|l|c|c|c|c|c|c|}
\hline $\begin{array}{c}\text { Interest in working } \\
\text { abroad }\end{array}$ & $\mathbf{2 0 0 8}$ & $\mathbf{2 0 0 9}$ & $\mathbf{2 0 1 0}$ & $\mathbf{2 0 1 1}$ & $\mathbf{2 0 1 2}$ & $\mathbf{2 0 1 3}$ \\
\hline yes & 13 & 18 & 16 & 17 & 20 & 24 \\
\hline no & 85 & 81 & 82 & 82 & 77 & 74 \\
\hline
\end{tabular}

* The percentages do not add up to 100.

Source: based on CBOS data for 2013.

The results of research conducted by CBOS in 2013 indicate that Poles' interest in travelling abroad to work is not weakening, but is actually growing. In 2013 one in four $(24 \%)$ of those surveyed expressed a readiness to leave.

Table 2 . Readiness to take up work abroad by sample age group (\%).*

\begin{tabular}{|l|c|c|c|c|c|c|}
\hline $\begin{array}{c}\text { Interest in } \\
\text { working } \\
\text { abroad }\end{array}$ & $\mathbf{1 8 - 2 4}$ & $\mathbf{2 5 - 3 4}$ & $\mathbf{3 5 - 4 4}$ & $\mathbf{4 5 - 5 4}$ & $\mathbf{5 5 - 6 4}$ & $\mathbf{6 5 +}$ \\
\hline yes & 62 & 38 & 30 & 14 & 9 & 1 \\
\hline no & 36 & 58 & 67 & 84 & 89 & 98 \\
\hline
\end{tabular}

* The percentages do not add up to 100.

Source: based on CBOS data for 2013. 
Between 2008 and 2013, the age structure of persons prepared to emigrate for work changed. They are increasingly younger Poles. In 2013, according to the CBOS survey the largest group, accounting for over half $(60 \%)$ of those in the entire age community, to declare willingness to emigrate for economic reasons were the 18 - 24 year olds. Young, well educated people with specific competences and skills choose emigration not only to earn. Among others they decide to take this step because they consider that in a more economically and socially conducive environment they will be better able to manage their professional development [CBOS 2013]. Many of them also hope that their ambitions can be fulfilled. They will be able to start their own businesses. This motivational imperative towards succeeding in the business field is exceptionally strong for them.

\section{Entrepreneurship and success - success and entrepreneurship - results of our survey}

"As is the thought, such is the deed"

Demosthenes

Entrepreneurship and success are interpreted by everyone individually. They ascribe a particular form to it and verbalising its meaning. Success in the context of entrepreneurial actions taken by citizens who emigrate from their mother country are a doubly interesting field of cognitive studies. For this reason the present author has made the effort to conduct research into identifying success in the context of entrepreneurial actions taken by Polish emigrants resident in Great Britain.

\section{Research methodology}

The survey carried out in May-June 2014 was of a descriptive and presentative nature. An analysis of the material gathered enabled a depictive representation of an entrepreneurial person to be produced, and an image of success to be created. The comparative summary enabled an answer to be found to the question of how Poles manage in the multicultural British environment, or whether emigration has allowed them to realise their personal career aims.

The overriding goal set before the survey was an attempt to define success in the context of entrepreneurial actions taken by Polish citizens resident in Great Britain. The research technique applied was an online survey. The measuring method used was completely dominant with relation to the standardised measuring instrument the questionnaire. The survey covered people who had been living in Britain for at least a year. Individuals were selected for the sample on the basis of a non-random choice of typical individuals. 


\section{Presentation of the set surveyed}

The survey covered 2,000 people, of whom 985 respondents had been living in Britain for over a year. This means that an individual respondent declared that during the period of at least twelve months preceding the survey they had been living and working in the UK. Among the Polish emigrants polled, there were slightly more men $(51.5 \%)$ than women $(48.5 \%)$. Taking into account the age criteria of those surveyed, it can be said that young and middle-aged respondents predominated. Just over a third (36.5\%) of those surveyed are under 30, while over half $(57.9 \%)$ are aged $30-39$.

Table 3. Demographic illustration of the group surveyed (in percentages).

\begin{tabular}{|c|c|c|}
\hline Variable & Variants of variable & \% share \\
\hline \multirow{3}{*}{ Sex } & women & 48.5 \\
\cline { 2 - 3 } & men & 51.5 \\
\hline \multirow{4}{*}{ Age } & $18-29$ & 36.5 \\
\cline { 2 - 3 } & $30-39$ & 57.9 \\
\cline { 2 - 3 } & $40-49$ & 2.7 \\
\cline { 2 - 3 } Education & 50 and over & 2.8 \\
\cline { 2 - 3 } & vocational & 38.0 \\
\cline { 2 - 3 } & secondary & 40.4 \\
\cline { 2 - 3 } & higher vocational - bachelor's & 21.0 \\
\cline { 2 - 3 } Time spent & degree & 0.6 \\
\cline { 2 - 3 } outside Poland & higher - master's degree & 4.2 \\
\cline { 2 - 3 } & 1-2 years & 6.1 \\
\cline { 2 - 3 } & 3-4 years & 16.8 \\
\cline { 2 - 3 } & 5-6 years & 31.6 \\
\cline { 2 - 3 } & 7-8 years & 41.4 \\
\hline
\end{tabular}

source: own material based on survey May/June 2014

In terms of education, there were as many people with secondary $(38.0 \%)$ as higher vocational education (40.4\%), and only a few had higher 2 nd degree or vocational education. As far as their stays abroad were concerned, over half of those surveyed (58.6\%) had been living as emigrants for longer than 8 years, with the largest group (31.6\%) being those in Britain for around 7-8 years. A small proportion (4.2\%) of the sample had been living in Britain no longer than 2 years.

To summarise the demographic make-up of the Polish emigrants in the UK, calculated on the basis of the survey results mentioned, they are slightly more likely to be men, more likely to be middle-aged, with secondary or higher education, and resident in the UK for 7-8 years. 
"Live, and not merely exist"

Plutarch

\section{Own business}

People who decide to emigrate are, as shown by the survey, mostly people working for somebody. Those working for themselves, i.e. running their own businesses, also form a significant group. Many of those polled (16.6\%) stated that they currently run their own businesses and may be described as entrepreneurs, which is testimony to their motivation towards achieving success.

A smaller minority of the women $(11.1 \%)$ conduct their own business than men $(21.6 \%)$. It is also worth pointing out that nearly half of those surveyed $(49.6 \%)$ stated that although they do not currently have their own business they planned to start one. Men dominate in this group of respondents $(60.0 \%)$ compared to women $(38.7 \%)$. This result indicates that men have a greater desire for self-realisation in business.

Meanwhile, in terms of the time spent abroad, those with their own businesses are those who have been abroad for at least 7-8 years (18.0\%). Among those intending to start up their own businesses predominate those who have been abroad longer than $1-2$ years $(70.7 \%)$.

\section{Satisfaction from work done}

Respondents polled admitted that so far their jobs basically brought them satisfaction, as stated by over half of them (67.9\%). Men dominate in this group of respondents $(72.0 \%)$ compared to women $(63.6 \%)$. However one fifth of those polled $(20.6 \%)$ admitted that their current job does not make them feel satisfied. Women dominate in this group of respondents $(27.6 \%)$ compared to men $(14.0 \%)$. The degree of satisfaction with the work done in conjunction with gender indicates that men are more often happy with the work they do, which may be due to the kind of work they do, a different level of ambitions and demands, and attitude to the work they do.

However with regard to the time spent abroad, the people satisfied with the work they do (64.36\%) are those who have been abroad for over 5 years. Among the unsatisfied respondents $(6.09 \%)$ the largest group are those who have been abroad for no longer than 4 years.

The degree of satisfaction with the work done combined with the length of stay abroad allows an assumption that the longer emigrants stay in Britain, the more often they find work corresponding to their preferences or have their own business, which increases their level of satisfaction. 


\section{Identification of entrepreneurship}

The idea of entrepreneurship for the respondents most often means taking up challenges in professional life (51.1\%), creating new solutions while carrying out everyday duties (38.2\%) and taking up challenges in their personal life (35.1\%). Another group of associations indicated by the respondents are starting their own business $(29.2 \%)$ and the freedom to make decisions in the work they do $(22.1 \%)$. Not until third place did the respondents claim that for them entrepreneurship means actions connected with gaining further professional qualifications $(14.0 \%)$, a change of job (13.5\%) and managing a group of subordinates within a company structure $(11.8 \%)$. Few people admitted to associating entrepreneurship with selfrealisation in the social sphere $(9.3 \%)$.

An analysis of the associations of entrepreneurship with starting a business in terms of gender indicates that men $(32.0 \%)$ are more likely than women $(26.4 \%)$ to identify entrepreneurship with starting their own business. Such an identification of associations of entrepreneurship in terms of gender is in line with the declarations of intent to start their own businesses.

Similarly, men more often than women identify entrepreneurship with taking up challenges in personal life (37.7\% against $32.4 \%$ ), the freedom to make decisions in the work they do (31.4\% against $12.3 \%)$ and gaining further professional qualifications $(21.3 \%$ against $6.3 \%)$. On the other hand women are more likely than men to associate entrepreneurship with taking up challenges in professional life $(57.5 \%$ against $45.0 \%)$, creating new solutions while carrying out tasks $(50.0 \%$ against $27.0 \%$ ) and self-realisation in the social sphere (13.6\% against 5.3\%).

\section{Sense of entrepreneurship}

A large majority of those surveyed answered the question "Do you consider yourself an enterprising person?" by stating that they do (69.4\%). Only a few of those polled (7.7\%) admitted that they do not consider themselves enterprising people. One in five $(22.8 \%)$ replied that it was difficult for them to say.

Men were far more likely $(77.3 \%)$ than women $(61.1 \%)$ to consider themselves enterprising people. Correlating the length of stay abroad with the sense of being enterprising shows that this index is higher for those who have been abroad for over 5 years $(64.06 \%)$ than under 5 years $(5.38 \%)$. The sense of entrepreneurship correlated to the length of stay abroad gives rise to the assumption that those emigrants who have lived for a relatively long time in Britain have a greater sense of their own authorship of their actions.

The respondents who described themselves as quite or definitely enterprising run their own businesses (7.81\%) or intend to start them in future (40.40\%). A small group of respondents admitted that in spite of identifying as entrepreneurial people they do not intend to start their own businesses (15.35). 


\section{Identification of success}

Success takes many forms in the eyes of the respondents, and there is no single dominant representation.

Among many comparisons, success is most commonly associated with self-realisation $(73.0 \%)$, a successful personal life (43.0\%), home/family (42.9\%), happiness and fulfilled dreams $(41.9 \%)$ and a successful professional life (41.1\%). The second group of associations identified with success consists of those referring to a sense of freedom and independence (33.0\%), having a good education (24.4\%), the desire to achieve status and the acknowledgement of peers (21.8\%) and the importance of health in life $(20.2 \%)$. Finally a third group of associations with the idea of success consists of those referring to a desire for social advancement (17.2\%), the acquisition of new skills in the field of knowledge of the rules and laws governing a given country $(13.7 \%)$, a feeling of emotional peace $(13.5 \%)$, being capable of managing in a culturally alien environment $(13.2 \%)$ and an active approach to matters concerning their own existence (11.1\%), as well as maintaining their dignity $(10.1 \%)$.

Correlating the qualifications of success with the criterion of sex provides results showing that for men the concept of success is identified mainly with a sense of self-realisation (19.52\%). Further associations with success stated by men are happiness and fulfilment of dreams (10.93\%), home and family (10.41\%) and successful personal life $(9.63 \%)$. They then mention freedom and independence $(8.23 \%)$, successful professional life $(7.35 \%)$ status and the acknowledgement of peers $(5.85 \%)$. Other associations are mentioned in less than $5.0 \%$ of responses.

Similarly, for women success also means a sense of self-realisation but to a slightly lesser degree than in the case of men (14.38\%). Then women mention associating success with a successful professional life (11.06\%), successful personal life (10.01\%) and home and family $(9.34 \%)$. Slightly further down the scale come happiness and fulfilment of dreams $(8.49 \%)$, a good education $(7.82 \%)$ and freedom and independence $(6,98 \%)$. Other associations are mentioned in less than $5.0 \%$ of responses.

More important for men than for women as markers of success are self-realisation, fulfilment of dreams, freedom and independence, and status and the acknowledgement of peers, which is in line with their greater likelihood to declare they wish to start their own business.

Both men and women identify success as the ability to satisfy a successful professional life with their personal life, but the other way round - for women professional life comes before their private life (if they can reconcile these two worlds). Interestingly, a good education represents success for women.

The results obtained point unambiguously to a desire be emigrants for homeostasis between their professional and personal lives. This is in line with previous considerations in this article. 


\section{Feeling of success}

An analysis of respondents answers to the question "Do you consider that you have achieved success in your life?" shows that a majority replied that they have achieved success $(63.2 \%)$. Only one in five admitted that they had not yet achieved success $(19.6 \%)$. Men $(68.7 \%)$ were far more likely than women $(57.5 \%)$ to claim that they had achieved success. Interestingly, a quarter of women found this hard to answer $(26.2 \%)$. Such results indicate that men are confident and do not necessarily want to admit defeat, while the women's responses and information about difficulties in defining themselves may be signs of low self-esteem and less confidence in their own achievements.

Comparing the declarations about success achieved with the length of stay abroad, it can be stated that those persons who have lived there longer than 5 years are far more likely to claim that they have achieved success (32.79\%) than those who have been there less than 5 years $(5.98 \%)$. Such a wide difference in the results may indicate that those who have spent longer as emigrants are more inclined to claim that they are successful.

Nearly half of those polled (49.13\%) identify as enterprising and successful people. One in ten of the people surveyed $(10.35 \%)$ states that by having their own business they can be said to be successful.

"To live is to fight"

Seneca

\section{Conclusion}

To summarise, success, by instilling many associations and reflecting the variety of factual states and states of mind of individuals and communities, is an exceptionally desirable way for both individuals and organisations to proclaim their presence. When included in the report on the process with a coherent effect of motivation, culture-based value system and aspirations, it predestines contemporary people to express their desires and realisations in a temporal/spatial reality. The Poles who live in Britain and consider themselves successful in life are an example of yearning for success. Emigration in a socio-economically supportive environment combined with the imperative of entrepreneurship has found its expression in the form of diverse representations of success including self-realisation, success in personal and professional life, a sense of happiness and dreams fulfilled, a sense of freedom and independence and many more. For them, every day is a challenge which they accept to realise their dreams and desires.

This article is woven into mainstream research on migration motivation of Polish citizens. In contrast to the previously occurring publications this article presents an analysis of the impact of immigration on the identification of the success 
of immigrants through the prism of entrepreneurship. The research despite the limitations associated with the availability of the study population (no directories) and limiting factors that contribute to economic emigration only as determinants of migration processes have significant advantages in both cognitive and practical areas. Identifying the basics of entrepreneurship can be a significant contribution to the changes in social and economic policy of the government and therefore stop the young and talented people in the country.

\section{Bibliography}

Altman H.Ch. (1997), Strategie sukcesu. Od Temistoklesa do Gandhiego - reguty skutecznej motywacji, Business Press, Warszawa.

Arndt R. (1998), Komunikacja miedzylud飞ka. Psychologia sukcesu, czyli przyjažn w interesach, Astrum, Wrocław.

Barszczewski A.W. (2013), Sukces w relacjach miedzyludzkich kluczem do zadowolenia w życiu i powodzenia w biznesie, Sowa, Warszawa.

Canfield J., (2005), The Success Principles: How to Get from Where You Are to Where You Want to $B e$, Element, New York.

Glinka B. (2013), Przedsiebiorczość polskich imigrantów w US A, Poltex, Warszawa.

Gładys - Jakóbik J. (2005), Różne oblicza i uvarunkowania sukcesu we wspótczesnej Polsce, SGH, Warszawa.

Grabowska - Lusińska I, Okólski M. (2009), Emigracja ostatnia ?, Scholar, Warszawa.

Kaczmarczyk P. (2011), Polska jako kraj emigracji i imigracji, Scholar, Warszawa.

Kaczmarczyk P. (2014), Recent Trends in International Migration in Poland The 2012 SOPEMI Report, CMR Working Paper, nr 71(129), Warszawa.

Lesińska M. Okólski M. (2013), Wspótczesne polskie migracje: strategie - skutki spoteczne - reakcja państwa, UW, Warszawa

Majewska-Opiełka I. (2003), Sukces firmy, GWP, Gdańsk.

McClelland D. (1961), The Acbieving Society, Van Nostrand Pricenton.

Mackay H. (2012), Mackaya MBA sprzedą̇y w prawdzinym świecie, MT Biznes, Warszawa.

Morawski W. (2001), Socjologia ekonomiczna, PWN, Warszawa.

Nkwocha Kizzi, (2013), Success in business, CreateSpace, London.

Scumaci D. (2014), Skazana na sukces, GWP, Gdańsk.

Sikorski Cz. (2011), Stosunek do sukecesu jako podstawa kultury organizacyjnej, IPISS [online] https://www.ipiss.com.pl/wp-content/uploads/downloads/2012/11/cz_sikorski_zzl_34_2008.pdf dostęp: 20 września 2014

Sikorski Cz. (2007), Drogi do sukcesu. Profesjonalizm kontra populistyczna kultura organizacyjna, Difin, Warszawa.

Qubein N.R. (1997), Droga do sukcesu, Warszawa. 
Główny Urząd Statystyczny, Departament Badań i Rynku Pracy (2013), Informacja o rozmiarach i kierunkach emigracji z Polski w latach 2004-2012, http://www.stat.gov.pl/gus/5840_14722_ PLK_HTML.htm. [październik 2013]

Główny Urząd Statystyczny (2013), Migracje aagraniczne ludności, Narodowy Spis Powszechny Ludności i Mieszkań 2011, http://www.stat.gov.pl/gus/5840_14782_PLK_HTML.htm. 